\title{
Future flood risk estimates along the river Rhine
}

\author{
A. H. te Linde ${ }^{1,2}$, P. Bubeck ${ }^{1}$, J. E. C. Dekkers ${ }^{3}$, H. de Moel ${ }^{1}$, and J. C. J. H. Aerts ${ }^{1}$ \\ ${ }^{1}$ Institute for Environmental Studies, Faculty of Earth and Life Sciences, VU University Amsterdam, Amsterdam, \\ The Netherlands \\ ${ }^{2}$ Deltares, Delft, The Netherlands \\ ${ }^{3}$ Department of Spatial Economics, Faculty of Economics and Business Administration, VU University Amsterdam, \\ Amsterdam, The Netherlands
}

Received: 20 June 2010 - Revised: 2 December 2010 - Accepted: 11 December 2010 - Published: 15 February 2011

\begin{abstract}
In Europe, water management is moving from flood defence to a risk management approach, which takes both the probability and the potential consequences of flooding into account. It is expected that climate change and socio-economic development will lead to an increase in flood risk in the Rhine basin. To optimize spatial planning and flood management measures, studies are needed that quantify future flood risks and estimate their uncertainties. In this paper, we estimated the current and future fluvial flood risk in 2030 for the entire Rhine basin in a scenario study. The change in value at risk is based on two land-use projections derived from a land-use model representing two different socio-economic scenarios. Potential damage was calculated by a damage model, and changes in flood probabilities were derived from two climate scenarios and hydrological modeling. We aggregated the results into seven sections along the Rhine. It was found that the annual expected damage in the Rhine basin may increase by between $54 \%$ and $230 \%$, of which the major part ( three-quarters) can be accounted for by climate change. The highest current potential damage can be found in the Netherlands ( 110 billion $€$ ), compared with the second ( 80 billion $€$ ) and third ( 62 billion $€$ ) highest values in two areas in Germany. Results further show that the area with the highest fluvial flood risk is located in the Lower Rhine in NordrheinWestfalen in Germany, and not in the Netherlands, as is often perceived. This is mainly due to the higher flood protection standards in the Netherlands as compared to Germany.
\end{abstract}

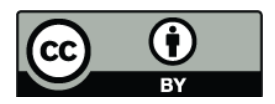

Correspondence to: A. H. te Linde (aline.te.linde@ivm.vu.nl)

\section{Introduction}

Over the last couple of decades Europe has witnessed a growth in the scale and frequency of extreme natural disasters. Storms and floods are the most frequent and costly extreme weather events occurring in Europe, representing $69 \%$ of the overall natural catastrophic losses. For example, flooding in the Elbe basin in 2002 caused approximately 8 billion $€$ of economic damage in Germany, Austria and the Czech Republic collectively (CEA, 2007). Total damage of the summer floods in 2007 in the UK amount to 4 billion $€$ (Environment Agency, 2007). In 2010, Poland suffered from major floodings, of which the total damages are yet unknown. When focusing on the Rhine basin in North-West Europe, flood events in 1993 and 1995 caused severe damage of 1.4 billion $€$ and 2.6 billion $€$, respectively (Engel, 1997; Glaser and Stangl, 2003; Brakenridge and Anderson, 2008).

The impact of flood events on societies and economies in the Rhine basin is likely to increase further as a result of two complementary trends. First of all, climate change is expected to increase the frequency and magnitude of flood peaks in the Rhine basin (Hooijer et al., 2004; Pinter et al., 2006). Annual maximum peak discharges are expected to increase by $3-19 \%$ in 2050 due to climate change (Kwadijk, 1993; Middelkoop et al., 2001; Vellinga et al., 2001). Te Linde et al. (2010) estimate an increase in the occurrence of an extreme 1/1250 per year flood event in the Lower Rhine delta by a factor of three to five in 2050. Secondly, the economic impact of natural catastrophes is increasing due to the growing number of people living in areas with a high flood exposure level, as well as the increased economic activity in these regions (e.g. Bouwer et al., 2007; Pielke Jr. et al., 2008). The International Commission for the

Published by Copernicus Publications on behalf of the European Geosciences Union. 
Protection of the Rhine (ICPR) estimated an increase in potential damage in flood-prone areas in the Rhine basin of 23\% between 1995 and 2005 (ICPR, 2005a).

These projected trends have led to an increased interest in a risk-based approach in water management, addressing both the probability and potential consequences of flooding (Merz et al., 2004; Buchele et al., 2006; De Bruijn and Klijn, 2009; Kreibich and Thieken, 2009; Wheater and Evans, 2009). Such an approach, for example, is currently stimulated by the EU Flood Directive 2007/60/EC (EU, 2007), obliging member states to create flood risk maps and basin-wide flood risk management plans (De Moel et al., 2009).

Quite a lot of literature exists on how the discharge regime in the Rhine may alter due to climate change (e.g. Kwadijk, 1993; Middelkoop et al., 2001; Menzel et al., 2006; Te Linde et al., 2010). However, in terms of land-use change and flood-damage potential only a few studies exist. The ICPR uses the Rhine Atlas approach to estimate aggregated flood damage for the whole Rhine basin (ICPR, 2001, 2005b). The Rhine Atlas damage evaluation has some flaws, though, for two reasons. Firstly, it has been recognized that the Rhine Atlas yields rather low damage potential values for different land-use classes compared to other studies and probably underestimates potential flood damage (Thieken et al., 2008; De Moel and Aerts, 2010). Secondly, the Rhine Atlas differentiates between only six different land-use classes; it uses a single urban class, whereas differentiation between urban classes for flood damage estimates is essential (Apel et al., 2009).

Research, however, on assessing current and future flood risk (addressing both flood probability and potential damage) is still in its early stages and a basin-wide assessment of flood risk is lacking. For the Rhine delta in the Netherlands two studies are available that calculate current and future flood risks (Aerts et al., 2008; Bouwer et al., 2010). These authors use a method in which the results of flood depths and land-use information are combined within a flood damage model. In this method projected land-use simulations using a land-use model are combined with inundation information to derive potential flood damages using stage-damage curves (Merz et al., 2007). Flood risk (in terms of expected annual damage) is assessed by multiplying the potential damage with the probability associated with the inundation information. Climate change is taken into account by simulating future discharges and probabilities using climate change scenarios as input for hydrological models (e.g. Te Linde et al., 2010). In addition to a current and future perspective, De Moel et al. (2010) also assessed the historical trends in the 20th century for flood damage in the central part of the Netherlands.

In order to conduct an assessment for trends in flood risk (in terms of flood probabilities and flood damage) for the Rhine basin we need to address the following two research issues. (1) A land-use model for the Rhine basin does not exist, and hence it is difficult to estimate future land use and potential flood damage. (2) Furthermore, despite existing research focusing on the (future) hydrology of the Rhine (e.g. Kwadijk, 1993; Middelkoop et al., 2001; Bronstert et al., 2002; Shabalova et al., 2003), few estimates exist for changes in future trends of low probability events. For the latter issue, climate impact simulations are required that allow for extreme value analysis techniques (Raff et al., 2009; Te Linde et al., 2010).

The goal of this paper is, therefore, to estimate current and future flood risk for the entire Rhine basin in a scenario study. For this, we first assessed changes in flood probability at various locations along the Rhine using climate scenarios and hydrological models. Second, we developed a landuse simulation model for the Rhine basin to generate future changes in land use. Third, these future land-use maps were used to estimate potential flood damage in flood-prone areas using a damage model. Finally, we multiplied flood probabilities with flood damage to derive current and future flood risk for the Rhine basin.

The remainder of this paper is organized as follows. Section 2 describes the case study area. Section 3 provides a description of the data and research method we used. Results are presented in Sect. 4 after which we discuss these results and provide conclusions in Sect. 5.

\section{Case study area: the Rhine basin}

The river Rhine originates in the Alps in Switzerland, forms part of the boundary between France and Germany and continues flowing through Germany before it enters the Netherlands at Lobith (Fig. 1a). The Rhine is one of the most important industrial transport routes in the world and connects one of the largest sea harbours, the port of Rotterdam, to the inland European markets and its large industrial complexes (Jonkeren, 2009). About 58 million people inhabit the river basin, of which 10.5 million live in flood-prone areas (ICPR, 2001). The average discharge at Lobith in the Lower Rhine is $2200 \mathrm{~m}^{3} \mathrm{~s}^{-1}$ and the maximum observed discharge was $12600 \mathrm{~m}^{3} \mathrm{~s}^{-1}$ in 1926 (Pinter et al., 2006).

Water management has heavily influenced the characteristics of the Rhine. Prior to the 19th century, the Rhine was a multi-channel braided river system upstream of Worms and meandering from that point downstream. However in order to reduce flooding, the Upper Rhine was canalized between 1817 and 1890 (Blackbourn, 2006). Furthermore, to aid shipping, engineers further rectified and canalized the main branch until 1955, causing additional acceleration of flood wave propagation in the Rhine (Lammersen et al., 2002).

The basin area is $185000 \mathrm{~km}^{2}$ and in particular the floodprone areas in the basin are densely populated (Fig. 1b). Hence, flood management has predominantly focused on major dike reinforcements along the Rhine over the last 20 30 years. Safety levels vary from $1 / 200$ to $1 / 500$ per year in 

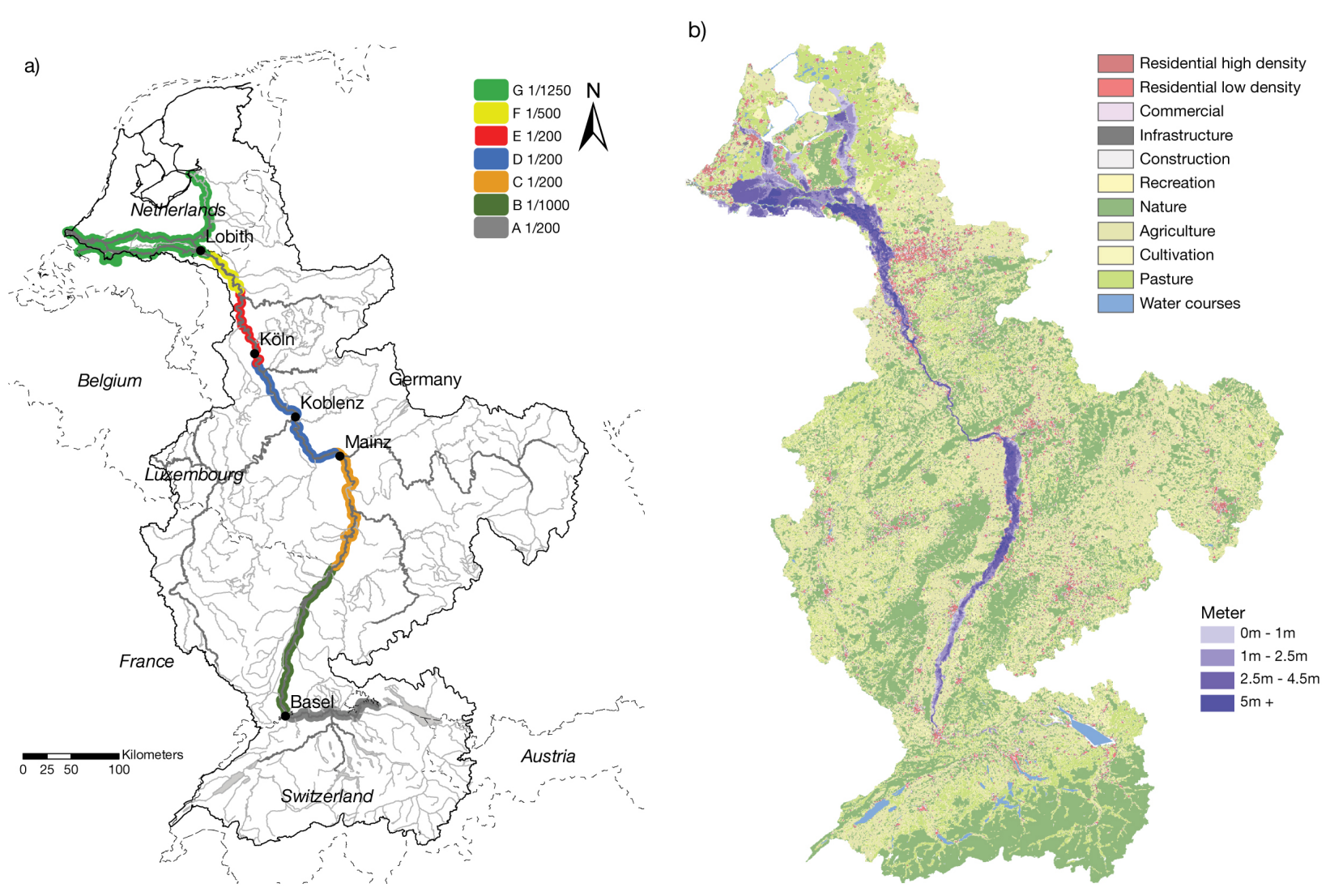

Fig. 1. Maps of the Rhine basin: (a) (estimated) safety levels and (b) land use in the reference situation. Figure (b) also shows the potential inundated area due to fluvial flooding from the Rhine.

Germany to $1 / 1250$ and $1 / 2000$ per year in the Netherlands. The design discharge that is associated with a safety level of $1 / 1250$ per year (the discharge used when designing flood defences) is estimated at $16000 \mathrm{~m}^{3} \mathrm{~s}^{-1}$ (Ministry of Transport, Public Works and Water Management, 2006a, Fig. 1a). Due to lower safety levels in Germany, floods may occur at upstream sections in Germany while the Dutch dike system will still prevent huge areas from inundation downstream (Gudden, 2004; Apel et al., 2006).

\section{Data and method}

We followed the steps displayed in Fig. 2 to estimate expected flood damage per year (risk) for the reference situation and different future scenarios for the year 2030 . Economic value of land-use classes determines the potential flood damage in case of a flooding event. Current landuse information was based on CORINE land cover data (Bossard et al., 2000). Future changes in flood damage were estimated using a land-use model, simulating future land use for two different socio-economic scenarios (see Sect. 3.1). Through combining existing basin-wide flood inundation depth maps (see Sect. 3.2) with land-use information, potential damage was calculated using a damage model (see Sect. 3.3). Flood risk was calculated by multiplying potential flood damage with the accompanying flood probability for different sections along the Rhine. Current flood probabilities were estimated using research by ICPR (2005b) and Silva and Van Velzen (2008) (Fig. 1a). Changes in flood probabilities were calculated using a hydrological model and two climate change scenarios (Te Linde et al., 2010) (see Sect. 3.4).

The flood damage calculations were performed at spatial grids of $100 \times 100 \mathrm{~m}$ and aggregated into seven regions along the Rhine (see regions A through G in Fig. 1a) and the entire basin to calculate expected damage per year. The steps used in this method, as well as the data and future scenarios, are described in detail below.

\subsection{Current and future land use}

Current land use is based on the CORINE land cover map for 2000 (Bossard et al., 2000) that has a resolution of $100 \times 100 \mathrm{~m}$. Future land-use projections from the EUruralis project exist for the whole of the European Union for the year 2030 (Verburg et al., 2008). However, these projections distinguish only a single urban land-use class and have a 


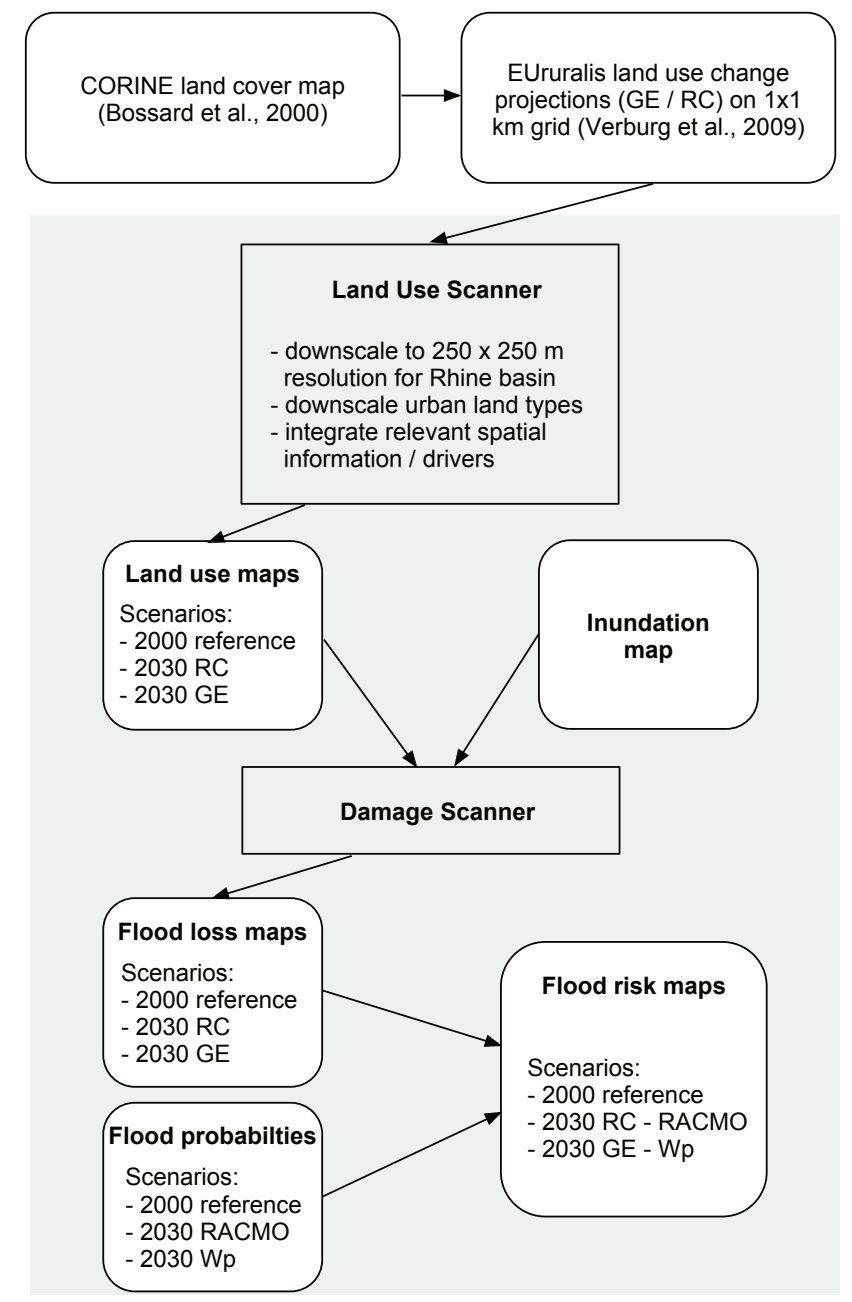

Fig. 2. Flowchart of the method used for estimating future flood risk.

relatively low resolution of $1 \times 1 \mathrm{~km}$, while it is important to have an accurate representation of urban land use in flood damage simulations (Bouwer et al., 2010). This is illustrated by De Moel and Aerts (2010) who show that urban land use contributes the largest share of flood damage $(\sim 80 \%)$, and because maximum damages differ substantially between different urban classes in their damage model (from 0.3 million $€$ hectare $^{-1}$ for recreational areas to 9.1 million $€$ hectare $^{-1}$ for high density residential areas), differentiation within urban land use is desirable for flood damage assessments.

To address this issue, we have set up a new and more detailed land-use model (the Land Use Scanner) to downscale land-use projections from the EUruralis project, both spatially and thematically. The Land Use Scanner for the Rhine basin is based on the method described by Hilferink and Rietveld (1999).

\subsubsection{Land Use Scanner}

The Land Use Scanner simulates future land use and is based on demand-supply interaction of land, whereby different sectors compete for allocation of land within land suitability and policy constraints (Loonen and Koomen, 2008). The model has previously been applied in a number of policyrelated research projects in European countries (Wagtendonk et al., 2001; Hartje et al., 2005; Koomen et al., 2005; Dekkers and Koomen, 2007). It was recently applied in studies on the long-term development of flood risk in the Netherlands and the evaluation of the effectiveness of various adaptation strategies (MNP, 2007; Aerts et al., 2008; Bouwer et al., 2010). The land-use model for the Rhine basin operates on a spatial resolution of $250 \times 250 \mathrm{~m}$ grid cells and provides information on 13 different land-use classes, such as infrastructure, nature, agricultural land and water, including six different urban functions (Fig. 1b).

\subsubsection{Scenarios and land-use claims}

To be able to simulate future land-use patterns with the Land Use Scanner, the expected increase or decrease of each land-use class (called "claims") has to be defined. These claims were derived from the EUruralis project (Verburg et al., 2008; Verburg and Overmars, 2009). In this project land-use projections and their underlying claims have been developed for four socio-economic scenarios, in line with the four scenarios in the Special Report on Emissions Scenarios (SRES) by IPCC (2000). For the present study, two of these projections and their land-use claims were selected: the "Global Economy" (GE) and the "Regional Community" (RC) scenarios which can be regarded as the upper and lower boundaries of possible future urban land-use change.

The "Global Economy" scenario reflects a future with high economic and population growth, international economic integration as well as little environmental concern on behalf of governments, resulting in a large increase in urban land-use functions with no restrictions on urban sprawl. The "Regional Communities" scenario, on the other hand, represents a future with low economic and population growth, a regional focus and strict environmental regulations enforced by governments, resulting in a substantially lower increase in urban areas and restrictions on urban sprawl.

We have used the NUTS3 level to derive land-use claims and as a starting point for our downscaling. NUTS3 corresponds to level 3 administrative units under the Nomenclature of Territorial Units for Statistics in Europe for which socio-economic data is available. These are mainly rural districts and cities with more than 100000 inhabitants. The land-use claims for the two future scenarios were derived by assessing the decrease or increase of each land-use class between the scenario projections and the baseline situation in 2000. 
Table 1. Suitability maps used for the "Land Use Scanner".

\begin{tabular}{llll}
\hline Category & Suitability map & Extent & Source \\
\hline Physical properties & Peat bog, marsh, moor & Basin & CORINE \\
& Slope & Basin & SRTM \\
& Population density & Basin & LandScan \\
Policy maps & Nature 2000 sites & Basin & DG Environment \\
& Flood retention areas & Germany & ICPR/TU Dortmund \\
& Flood zone (1/100 per year) & Basin & ICPR Rhine Atlas \\
& Flood zone (extreme event) & Basin & ICPR Rhine Atlas \\
Relational maps & Distance to metropolitan areas & Basin & ESRI \\
& Distance to long-distance train stations & Basin & TU Dortmund \\
& Distance to passenger railway stations & Basin & TU Dortmund \\
& Distance to motorway exits & Basin & TU Dortmund \\
& Distance to international airports & Basin & ESRI \\
& Distance to road network & Basin & ESRI \\
& Distance to major rivers & Basin & ESRI \\
& Neighborhood statistics & Basin & Own analysis \\
\hline
\end{tabular}

\subsubsection{Downscaling}

We spatially scaled down the land-use change projections from the NUTS 3 polygons to $250 \times 250 \mathrm{~m}$, which is the required level of detail needed for the Land Use Scanner. Furthermore, the single urban land-use class distinguished in the EUruralis projections was distributed into five urban land-use classes; residential land use, commercial, recreation, infrastructure and construction/mines. Using the CORINE 2000 land cover map the percentage of the five different urban land-use categories of total urban land use was calculated for each NUTS3 region within the study area. Subsequently, the total change in urban land use was assessed by comparing the EUruralis projections for 2030 to the start year, again at the NUTS3 regional level. The resulting change in total urban land use was then distributed over the five urban land-use classes according to the previously established divisions, taking into account the storylines for the two scenarios.

On top of differentiating the EUruralis urban land-use class, an extra residential class representing high-density residential areas was defined using the LandScan population data base (Landscan, 2009). This was done because the CORINE 2000 land cover data makes very little distinction between high and low urban density residential areas.

\subsubsection{Suitability maps}

The land-use claims provide information on the scale of future land-use change but give no indication as to where these claims might be realized. This allocation process is carried out by the Land Use Scanner on the basis of suitability maps. These maps give a definition for every location (grid cell) of its attractiveness for the different land-use types available, depending on its current land use, physical properties, operational policies and expected relations to nearby land-use functions (Ritsema van Eck and Koomen, 2008). For example, a location (grid cell) with a steep slope (physical property) that is situated in a nature protection area (operational policy) and far away from existing urban infrastructure (relation to nearby land use) is thus considered as highly unsuitable for the realization of a residential land-use claim. The suitability maps can also be used to further reflect the effect of socio-economic scenarios and thus the land-use change simulations by integrating flood-risk specific information. For example, the regional communities scenario assumes a world with a regional focus and strict environmental regulations enforced by governments. To reflect this, the $1 / 100$ per year flood zone, which is mainly embanked river foreland, is given a low suitability value for further urbanization, a policy that has already been adopted in Germany. In contrast, the global economy scenario assumes a world where governments have little environmental concern, resulting in a large increase in urban land-use functions with no restrictions on urban sprawl. We, therefore, simulated land use according to this scenario without limitations as far as the $1 / 100$ per year flood zone is concerned. Moreover, the suitability of urban areas close to a river course is increased in the global economy scenario as it is assumed that more people would like to live near the water and are willing to pay for this location. This development has also been observed in the past during periods of economic growth (ICPR, 2005b). An overview of the suitability maps used for the Land Use Scanner for the Rhine basin is given in Table 1 . 


\subsection{Inundation map}

One of the inputs for the flood damage model is a map displaying the water depth of a possible flooding event in the entire Rhine basin. Such a map was developed in 2001 by the International Commission for the Protection of the Rhine (ICPR), known as the Rhine Atlas (ICPR, 2001). This atlas contains a collection of maps that displays the potential flooded area in the Rhine basin at different flooding probabilities (1/10 per year, 1/100 per year, and "extreme", without a probability estimate).

We used only the "extreme" situation to indicate the inundated area in the case of flooding, since safety levels along the Rhine are all higher than 1/100 per year (Fig. 1a). Based on the Rhine Atlas, we cannot predict how the flood extent will change in the future and therefore we have assumed that the inundated areas for the reference situation and in 2030 are the same. For the Netherlands, we have used flood risk maps made available by the Dutch government that are based on multiple inundation model runs (Van den Berg et al., 2010). We have only included inundated areas that are prone to flooding by the river Rhine and not areas that are influenced by storm surges from the sea.

\subsection{Flood damage}

Potential flood damage can be assessed in various ways, ranging from the use of very detailed, object-based data to the use of aggregated asset values per hectare (or square meter) for a certain land-use category (Messner et al., 2007). Given the spatial and temporal scale of the present study, which looks at the development of flood risk on a basinwide level in the future, we used a simple damage model for land use categories, the Damage Scanner (Aerts et al., 2008; Bouwer et al., 2010; Klijn et al., 2007). This model is based on two input parameters: water depth and land use. Potential damage is calculated by the model using so-called damage functions that define for a land-use category the damage that can be expected when a respective inundation level occurs.

The model applies damage functions for the 13 land-use classes distinguished by the Land Use Scanner and reflects predominantly direct tangible damage caused by physical contact between economic assets and flood water. Note that direct intangible losses such as loss of life are not reflected by the model. However, the Damage Scanner also implicitly comprises approximately $5 \%$ of indirect damages as a surcharge on direct damages. Indirect damages refer to a loss of turnover due to business interruption during a flood event and can make up a substantial share of total flood damages (RebelGroup, 2007).

\subsection{Climate change scenarios for changes in flood probabilities}

Figure 1a shows current safety levels for seven regions along the main Rhine branch. In the Netherlands, there is a legal standard for flood defence safety levels. In Germany, dike heights are often legally defined and the related safety levels are estimated and described by ICPR (2005b) and Silva and Van Velzen (2008). The differences in safety levels were used to distinguish the regions for which aggregated flood damage and flood risk can be calculated. The seven regions have different surface areas. The larger the surface area, the larger the aggregated damage and risk will be, since we assume that at the given probabilities the entire region will flood. Nevertheless, we made no corrections in our results for the different surface areas of the seven regions.

We assumed flooding occurs at probabilities corresponding to the safety levels in the reference situation. Hence, we did not simulate flood damage due to dike failures that may occur at lower probabilities and furthermore assumed that dike heights will not change in the future. The current policy in the Netherlands, however, foresees adaptation of the flood defences (i.e. dike heightening or lowering of the flood plains) when flood probability increases in order to maintain current safety levels.

We used two climate change scenarios (a moderate and an extreme scenario) to estimate future changes in flood probabilities along the main Rhine branch, which were taken from Te Linde et al. (2010). The first climate scenario (referred to from now on as $\mathrm{Wp}$ ) represents an extreme climate change scenario, based on Van den Hurk et al. (2006) and describes the most extreme scenario out of four in terms of winter precipitation and resulting floods along the Rhine in 2050 (Te Linde, 2007). This climate scenario corresponds with a $2{ }^{\circ} \mathrm{C}$ increase in global temperature in 2050 with respect to 1990 and changes in atmospheric circulation resulting in drier summers and wetter winters.

The second climate scenario (further referred to as "RACMO") displays more moderate climate change effects and follows the output of the RACMO2.1 regional climate model (Lenderink et al., 2003; Meijgaard et al., 2008; Bakker and Van den Hurk, 2009). This scenario corresponds with the IPCC SRES-A1B scenario and projects more spatial variation in meteorological changes than the $\mathrm{Wp}$ scenario does.

Both climate scenarios are available in time series of 35 years, and were resampled into time series of 1000 years of daily data. These resampled times series were subsequently used to drive the hydrological model HBV (Bergström, 1976) and to simulate river discharges and related flood peak probabilities (Te Linde et al., 2010). By comparing current flood probabilities with future flood probabilities, changes in flood-peak probability were derived for the seven regions along the Rhine (see Table 2). Te Linde et al. (2010) evaluated changes in flood probabilities between 
Table 2. Climate change scenarios for increased flooding probabilities in 2030. Flooding probabilities (per year) for the reference situation are estimated based on literature. The probability $(p)$ increase is displayed as a factor (* estimate, based on Silva and Van Velzen (2008) and on the Evaluation of the Action Plan on Floods (ICPR, 2005a)).

\begin{tabular}{|c|c|c|c|c|c|}
\hline \multirow[b]{2}{*}{ Region } & Reference* & RACMO & $\mathrm{Wp}$ & RACMO & $\mathrm{Wp}$ \\
\hline & \multicolumn{3}{|c|}{$p$} & \multicolumn{2}{|c|}{$p$ incr. } \\
\hline Alpine A & $1 / 200(0.0050)$ & $1 / 139(0.0072)$ & $1 / 64(0.0157)$ & 1.4 & 3.1 \\
\hline Upper Rhine B & $1 / 1000(0.0010)$ & $1 / 691(0.0014)$ & $1 / 261(0.0038)$ & 1.5 & 3.9 \\
\hline Upper Rhine C & $1 / 200(0.0050)$ & $1 / 160(0.0062)$ & $1 / 77(0.0129)$ & 1.3 & 2.6 \\
\hline Middle Rhine D & $1 / 200(0.0050)$ & $1 / 159(0.0063)$ & $1 / 80(0.0125)$ & 1.3 & 2.5 \\
\hline Lower Rhine E & $1 / 200(0.0050)$ & $1 / 134(0.0075)$ & $1 / 80(0.0125)$ & 1.5 & 2.5 \\
\hline Lower Rhine F & $1 / 500(0.0020)$ & $1 / 327(0.0031)$ & $1 / 162(0.0062)$ & 1.5 & 3.1 \\
\hline \multirow{2}{*}{ Delta G } & $1 / 1250(0.0008)$ & $1 / 673(0.0015)$ & $1 / 437(0.0023)$ & \multirow{2}{*}{1.9} & \multirow{2}{*}{2.9} \\
\hline & $1 / 2000(0.0005)$ & $1 / 1080(0.0015)$ & $1 / 702(0.0023)$ & & \\
\hline
\end{tabular}

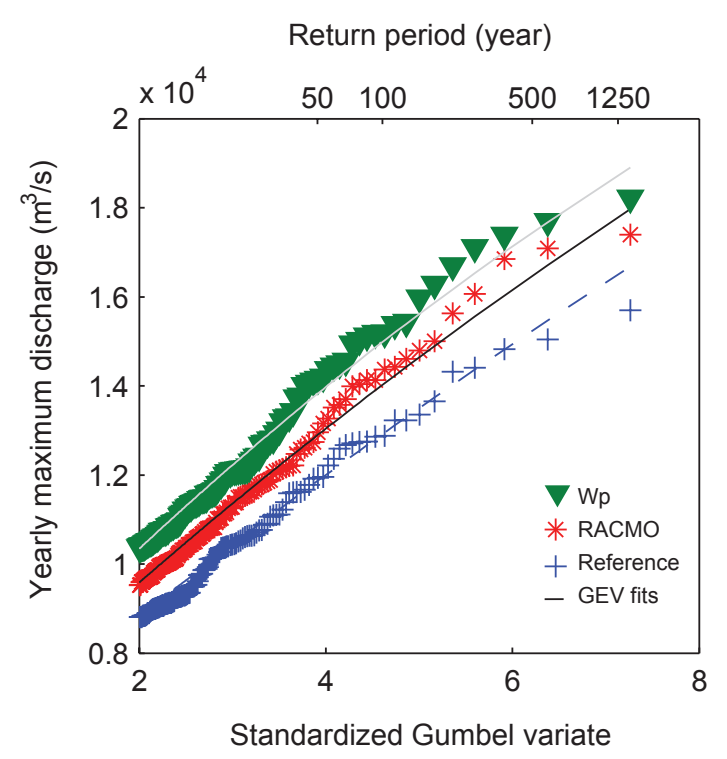

Fig. 3. Extreme value distributions of annual maximum discharge at Lobith, and Generalized Extreme Value (GEV) fits (lines) for the reference situation, and the RACMO and $\mathrm{Wp}$ climate change scenarios for the year 2050 (adapted from Te Linde et al., 2010).

1990 and 2050. Since the reference year in this study is 2000 , and the scenario year 2030, we divided the projected changes in flood probabilities by Te Linde et al. (2010) by two in order to take the shorter timescale into account.

\section{Simulation results}

\subsection{Discharges and probabilities}

Figure 3 shows an extreme value plot for annual maximum discharges at Lobith, for the year 1990 and two climate change scenarios for 2050. The results represent 1000-year runs for the reference and each climate change scenario (Wp and RACMO). From the simulation results it can be derived that the discharge corresponding to a probability of $1 / 1250$
Table 3. Surface percentages of different land use classes in the flood prone area of the Rhine basin, for the reference situation in 2000, and the RC and GE scenarios in 2030. Percentages and Euros in Tables 3 through 7 are rounded to two significant digits.

\begin{tabular}{|c|c|c|c|c|c|}
\hline \multirow[b]{2}{*}{ Land use class } & Reference & $\mathrm{RC}$ & GE & $\mathrm{RC}$ & GE \\
\hline & \multicolumn{3}{|c|}{ Area $(\%)$} & \multicolumn{2}{|c|}{ Change $(\%)$} \\
\hline Residential High Density & 3.7 & 4.3 & 5.4 & 16 & 45 \\
\hline Residential Low Density & 9.0 & 11 & 14 & 23 & 47 \\
\hline Commercial & 3.7 & 4.3 & 5.2 & 18 & 42 \\
\hline Infrastructure & 1.0 & 1.1 & 1.1 & 14 & 13 \\
\hline Construction/mines & 0.69 & 0.77 & 0.77 & 12 & 11 \\
\hline Recreation & 1.7 & 2.0 & 2.2 & 14 & 28 \\
\hline Nature & 9.4 & 19 & 11 & 110 & 21 \\
\hline Agriculture & 23 & 19 & 20 & -16 & -15 \\
\hline Cultivation & 10 & 10 & 10 & 2.3 & 1.7 \\
\hline Pasture & 37 & 36 & 40 & -2.7 & 5.9 \\
\hline
\end{tabular}

per year at Lobith increases by $16 \%$ for the Wp scenario and by $13 \%$ for the RACMO scenario. The discharge currently corresponding to the $1 / 1250$ event (about $16000 \mathrm{~m}^{3} \mathrm{~s}^{-1}$ ) will increase to $1 / 460$ per year for the RACMO scenario and $1 / 265$ per year for the $\mathrm{Wp}$ scenario, meaning the probability increases by a factor of 2.7 to 4.7 , respectively (Te Linde et al., 2010). Similar projected changes in flood probabilities are available for several locations along the Rhine branch, representing the regions $A$ through $\mathrm{G}$ in Fig. 1a with different safety levels. The projected increases in flood probabilities for 2030 range from a factor of 1.3 to 3.8, depending on region and climate change scenario (Table 2).

\subsection{Land-use change}

Table 3 shows surface percentages of land-use classes in the flood prone area of the Rhine, according to the CORINE land cover map. Agriculture, cultivation and pasture have the largest combined share of $71 \%$ in the reference situation. High and low density residential and commercial areas comprise $17 \%$ of the total basin area. The RC scenario for 


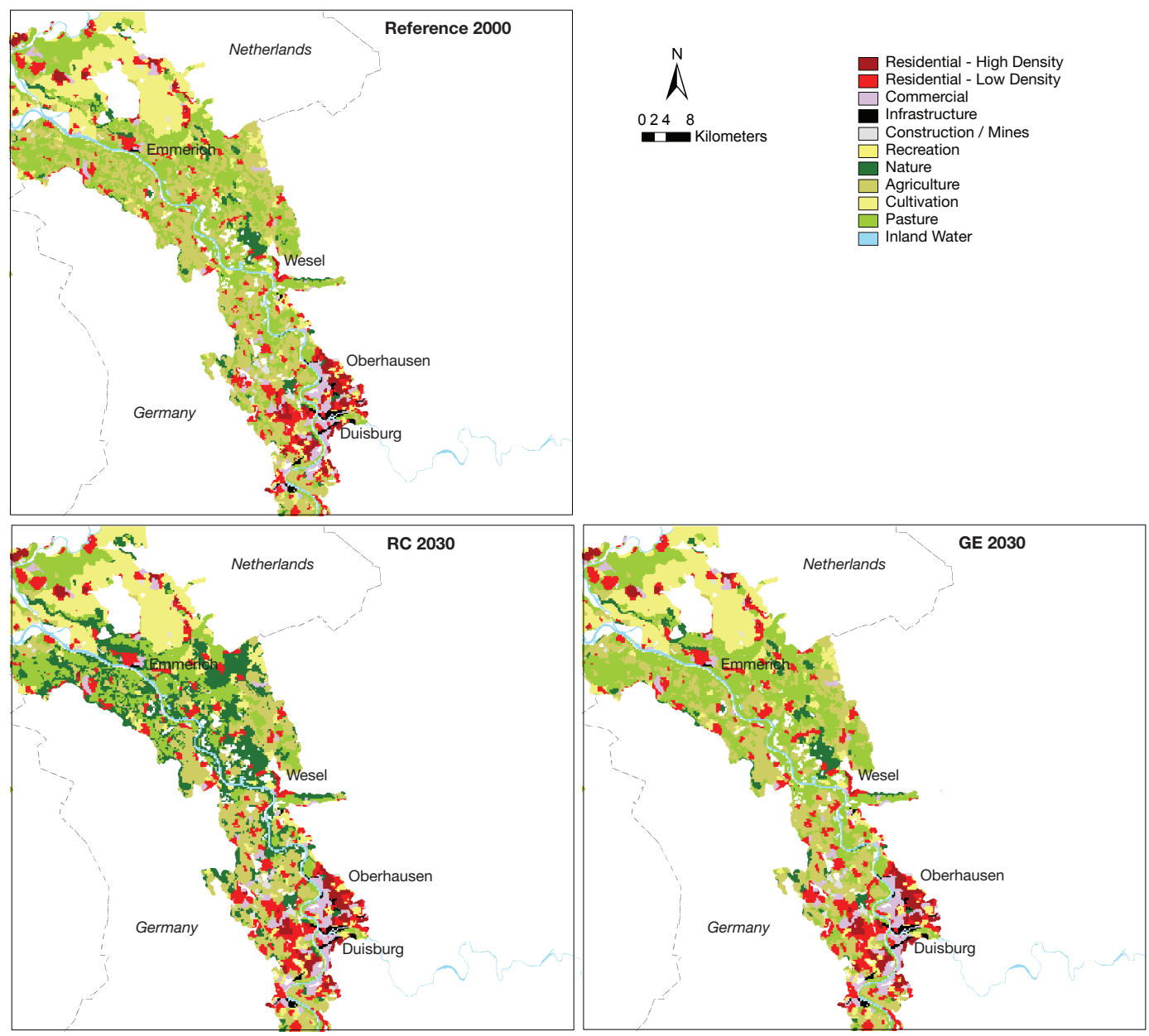

Fig. 4. Land use maps for the reference year 2000, and for 2030 under the RC and GE socio-economic scenarios. The image is zoomed on the Lower Rhine near the border between Germany and the Netherlands, and shows only land use types in flood-prone areas.

2030 displays by far the largest increase in nature (110\%), whereas residential and commercial areas each increase on average by $19 \%$. In the GE scenario, the residential and commercial areas each increase on average by $44 \%$. Both scenarios project a decrease in agricultural area $(\sim-15 \%)$. Cultivated area and pasture remain fairly stable in both scenarios (less than $6 \%$ change).

These trends are also illustrated in Fig. 4, showing output maps of the land-use simulations. The map shows a clear increase in urbanized areas close to the river in the GE scenario, whereas the increase in nature is the most apparent change in the RC scenario. These results obviously correspond to the scenario descriptions that were used in the simulations (see Sect. 3.1.4).

\subsection{Flood damage}

Table 4 and Fig. 5a display the expected damage aggregated for the seven regions along the Rhine. For the reference year (2000), we estimated the total potential damage for the whole basin to be 300 billion $€$. This is substantially more than the ICPR estimate of 200 billion $€$ (ICPR, 2001). The ICPR damage estimates are, however, recognized to be rather low compared to other methods and studies. Several land-use types such as residential and commercial areas or agriculture have substantially lower maximum damage values compared to the damage model applied in our study (for more details ICPR, 2001; Thieken et al., 2008; De Moel and Aerts, 2010). This can be explained, amongst others, by the observation that the results of the Damage Scanner also comprise a share of, on average, $5 \%$ indirect damages, which is not included in the Rhine Atlas estimates.

The expected damage gradually increases downstream. The delta in the Netherlands (region G) is the largest and most densely populated region, and has therefore the highest potential damage, both in the reference situation as well as in the future projections of both socio-economic scenarios. Between the two scenarios, the RC scenario yields the lowest increase in potential damage: $7.5 \%$ over the entire basin. In most regions potential damage changes little, with the 
Table 4. Expected damage for different regions in 2000 and 2030 (at 2000 prices) (* the estimate of the ICPR, 2005a).

\begin{tabular}{lcccccc}
\hline Region & $\begin{array}{c}\text { Reference } \\
\text { billion } €\end{array}$ & $\begin{array}{c}\text { ICPR } \\
2005^{*}\end{array}$ & $\begin{array}{c}\text { Scen RC } \\
\text { billion } €\end{array}$ & $\begin{array}{c}\text { Scen GE } \\
\text { billion } €\end{array}$ & $\begin{array}{c}\text { Scen RC } \\
\text { Change (\%) }\end{array}$ & $\begin{array}{c}\text { Scen GE } \\
\text { Change (\%) }\end{array}$ \\
\hline Alpine A & 0.46 & 0.0 & 0.39 & 0.50 & -0.18 & 8.2 \\
Upper Rhine B & 21 & 1.6 & 21 & 26 & 1.8 & 18 \\
Upper Rhine C & 58 & 11 & 62 & 73 & 5.9 & 20 \\
Middle Rhine D & 15 & 1.5 & 12 & 18 & -23 & 15 \\
Lower Rhine E & 71 & 22 & 80 & 90 & 11 & 21 \\
Lower Rhine F & 25 & 170 & 30 & 37 & 18 & 34 \\
Delta G & 110 & 120 & 140 & 7.6 & 20 \\
\hline Total & 300 & 200 & 320 & 380 & 7.5 & 21 \\
\hline
\end{tabular}
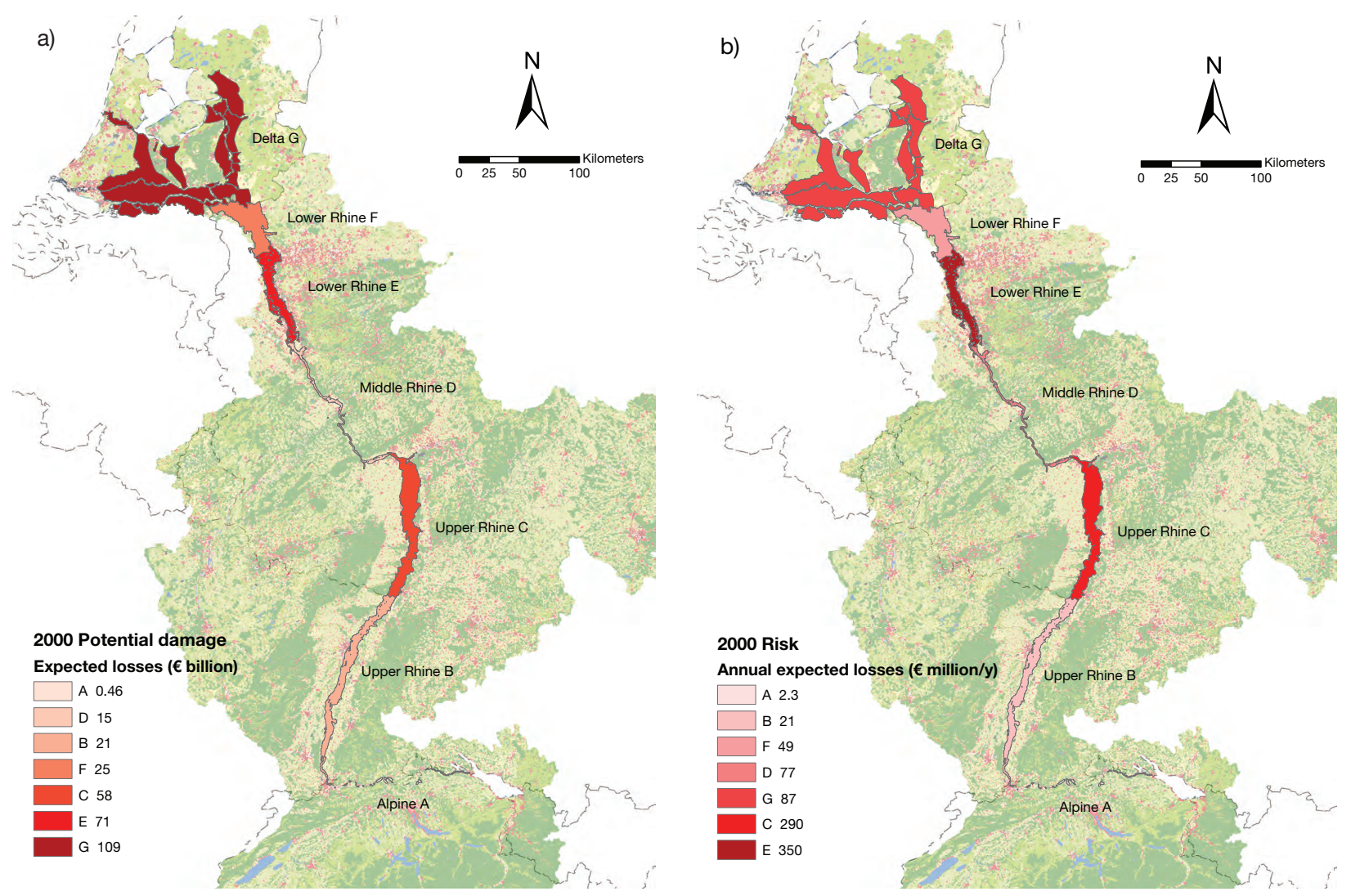

Fig. 5. Potential damage (a) and flood risk (b), aggregated to seven regions along the Rhine.

exception of the Lower Rhine region $(\mathrm{F})(+18 \%)$. In some areas, such as the Middle Rhine, the RC scenario even projects a decrease in potential damage. The GE scenario gives an overall larger increase in potential damage (21\%). Moreover, expected damage seems to increase substantially in almost all regions, often by more than $15 \%$ and ranging up to $34 \%$.
Results of expected damage per land-use class for the entire Rhine basin are presented in Table 5. The potential damage of residential and commercial areas in the Rhine basin is 200 billion $€$, which comprises $63 \%$ of the total damage, and is projected to increase to 260 billion $€(\mathrm{RC})$ and 320 billion $€(\mathrm{GE})$ (Table 5). Agriculture, cultivation and pasture comprise 93 billion $€$ damage (29\% of the total damage), which is projected to decrease to 61 billion $€(R C)$ and 63 billion $€(\mathrm{GE})$. 
Table 5. Expected damage for different land use categories in 2000 and 2030 (at 2000 prices).

\begin{tabular}{|c|c|c|c|c|c|c|c|c|}
\hline \multirow[b]{2}{*}{ Land use class } & Reference & $\mathrm{RC}$ & GE & Reference & $\mathrm{RC}$ & GE & $\mathrm{RC}$ & GE \\
\hline & \multicolumn{3}{|c|}{ billion $€$} & \multicolumn{3}{|c|}{$(\%)$} & \multicolumn{2}{|c|}{ Chng (\%) } \\
\hline Residential H D & 73 & 86 & 110 & 23 & 25 & 27 & 18 & 46 \\
\hline Residential L D & 85 & 120 & 150 & 27 & 34 & 36 & 39 & 72 \\
\hline Commercial & 42 & 53 & 66 & 13 & 16 & 17 & 28 & 59 \\
\hline Infrastructure & 7.0 & 6.3 & 6.2 & 2.2 & 1.8 & 1.5 & -11 & -12 \\
\hline Constr/mines & 2.5 & 2.9 & 2.9 & 0.8 & 0.9 & 0.7 & 19 & 17 \\
\hline Recreation & 4.7 & 2.0 & 2.3 & 1.5 & 0.6 & 0.6 & -57 & -51 \\
\hline Nature & 9.1 & 14 & 7.9 & 2.9 & 4.1 & 2.0 & 56 & -13 \\
\hline Agriculture & 31 & 15 & 16 & 10 & 4.5 & 4.0 & -49 & -47 \\
\hline Cultivation & 32 & 30 & 30 & 10 & 8.8 & 7.5 & -5.4 & -6.1 \\
\hline Pasture & 30 & 16 & 17 & 10 & 4.6 & 4.3 & -48 & -43 \\
\hline
\end{tabular}

Table 6. Basin-wide annual expected damage (risk) in million $€$ per year. The factor of change is displayed in brackets. The reference year is 2000 and the scenarios represent 2030.

\begin{tabular}{lllcl}
\hline & & \multicolumn{3}{c}{ Socio-economic scenario } \\
\cline { 3 - 5 } & & Reference & RC & GE \\
\hline Climate & Reference & 880 & $950(7.5 \%)$ & $1100(27 \%)$ \\
scenario & RACMO & $1300(43 \%)$ & $1400(54 \%)$ & $1600(81 \%)$ \\
& Wp & $2300(160 \%)$ & $2500(180 \%)$ & $2900(230 \%)$ \\
\hline
\end{tabular}

\subsection{Flood risk}

Figure $5 b$ shows estimates of expected annual flood damage in the reference year (2000) for the seven regions along the Rhine. In contrast with potential damage (Fig. 5a), the highest flood risk estimates are not found in the Dutch Delta $(\mathrm{G})$, but rather in the Lower Rhine (E) in the German state Nordrhein-Westfalen and in the Upper Rhine (C). This is the result of the substantially higher flood protection levels in the Delta region G, which obviously determines and lowers the flood-risk estimates to a large extent. This also implies that uncertainties of flood probabilities heavily affect the reliability of (future) flood-risk estimates in this region.

For the future risk projections, the RACMO climate scenario is combined with the RC socio-economic scenario and $\mathrm{Wp}$ with the GE scenario. The combination RACMO$\mathrm{RC}$ can be considered as the lower estimate and Wp-GE as the upper estimate in the risk simulations. Basin-wide results are displayed in Table 6. The flood risk estimates of the scenarios show a large variation. In the reference situation, we estimate the basin-wide expected annual flood damage to be 880 million $€$ on average per year. The RACMORC scenario projects the risk to increase to 1400 million $€$ per year, an increase of $54 \%$. The Wp-GE scenario projects a much larger increase in flood risk, tripling it to 2900 million €per year (an increase of 230\%).

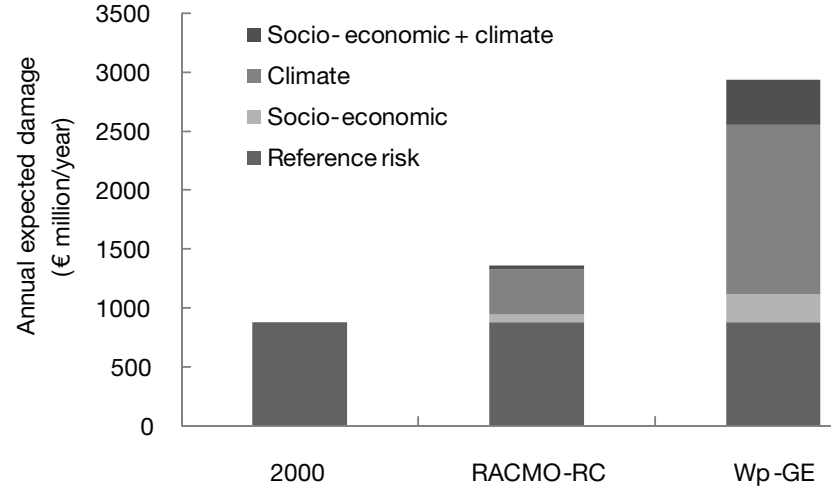

Fig. 6. Basin-wide annual expected flood damage (risk) for 2030, compared to the reference situation.

The contribution made by climate change is considerably larger than socio-economic change in both scenario combinations. Due to climate change, basin-wide flood risk increases by $43-160 \%$, whereas land-use change results in an increase of $6.5-27 \%$ (Table 6). In order to illustrate the relative increase of annual expected damage due to each of the driving forces, we displayed the basin-wide flood risk scenarios in a bar chart (Fig. 6). The bar chart displays the contributions to change in annual expected damage, from (a) climate change only, (b) socio-economic change only, and (c) the combination of both impacts. Climate change accounts for $\sim$ three-quarters $(6 / 8)$ of the increase, whereas socioeconomic change only results in $\sim 1 / 8$ of the total increase in annual expected damage. The combination of impacts adds the remaining $\sim 1 / 8$ to both scenarios, respectively.

As this is the first assessment of basin-wide future flood risk, it is interesting to compare different sections along the Rhine and to evaluate if differences with regard to the drivers of future flood risk can be observed. To assess differences between regions along the Rhine, Table 7 shows annual expected damage for seven regions. Bar charts similar to 
Table 7. Annual expected damage (risk) in million $€$ per year for different regions in 2000 and 2030 (at 2000 prices).

\begin{tabular}{|c|c|c|c|c|c|c|c|c|c|}
\hline \multirow[b]{2}{*}{ Region } & \multicolumn{3}{|c|}{ Reference situation } & \multicolumn{3}{|c|}{ RACMO and RC } & \multicolumn{3}{|c|}{$\mathrm{Wp}$ and $\mathrm{GE}$} \\
\hline & $p$ & billion $€$ & million $€ \mathrm{yr}^{-1}$ & $p$ & billion $€$ & million $€ \mathrm{yr}^{-1}$ & $p$ & billion $€$ & million $€ \mathrm{yr}^{-1}$ \\
\hline Alpine A & 0.0050 & 0.46 & 2.3 & 0.0072 & 0.39 & 2.8 & 0.0157 & 0.50 & 7.9 \\
\hline Upper Rhine B & 0.0010 & 21 & 21 & 0.0014 & 21 & 31 & 0.0038 & 26 & 98 \\
\hline Upper Rhine C & 0.0050 & 58 & 290 & 0.0062 & 62 & 390 & 0.0129 & 73 & 940 \\
\hline Middle Rhine D & 0.0050 & 15 & 77 & 0.0063 & 12 & 78 & 0.0125 & 18 & 220 \\
\hline Lower Rhine E & 0.0050 & 71 & 350 & 0.0075 & 80 & 590 & 0.0125 & 90 & 1100 \\
\hline Lower Rhine F & 0.0020 & 25 & 49 & 0.0031 & 30 & 91 & 0.0062 & 37 & 230 \\
\hline Delta G & $\begin{array}{l}0.00080 \\
0.00050\end{array}$ & 110 & 87 & $\begin{array}{l}0.0015 \\
0.00093\end{array}$ & 120 & 180 & $\begin{array}{l}0.0023 \\
0.0014\end{array}$ & 140 & 310 \\
\hline Total & & 300 & 880 & & 320 & 1400 & & 380 & 2900 \\
\hline
\end{tabular}

Fig. 6 are shown in Fig. 7, but now disaggregated to seven regions along the Rhine. The bar charts show large variations in base risk and flood risk projections between regions, and, like the basin-wide projections, the dominant contribution of climate change to increased flood risk.

The Alpine area (A) and the Upper Rhine (B) display hardly any annual expected damage at the vertical scale they are presented (less than 100 million $€$ per year). Just as we have seen in Fig. 5b for the reference flood risk, projections for annual expected damage in 2030 are the highest in the Upper Rhine (C) (up to 940 million $€$ per year in the Wp-GE scenario, an increase of 220\%) and the Lower Rhine (E) (up to 1100 million $€$ per year, an increase of $210 \%$ ). The Middle Rhine (D), the Lower Rhine up to the Netherlands $(\mathrm{F})$, and the Dutch Delta $(\mathrm{G})$ show risk projections of between 220 and 310 million $€$ per year in the Wp-GE scenario.

For the different regions, the relative contribution of climate change to increased flood risk varies between $5 / 8$ and $7 / 8$, whereas socio-economic change results in zero to $2 / 8$ of the total increase in annual expected damage.

\section{Discussion and conclusions}

The aim of this paper was to estimate future flood risk in 2030 for the entire Rhine basin. We took the year 2000 as a reference and used scenarios in a model simulation to assess changes in flood probability due to climate change, and to assess changes in potential damage due to land-use change. The combined simulations provided different projections for future flood risk.

It was found that, in absolute terms, potential flood damage is highest in the Dutch Delta region $(\mathrm{G})$, namely 110 billion $€$, compared to 71 billion $€$ of the second highest value in the Lower Rhine region (E). Flood risk (damage $\times$ probability) is, on the other hand, much higher in other regions, most notably in the Lower Rhine region E (350 million $€$ per year) and the Upper Rhine C
(290 million $€$ per year), whereas the Dutch Delta region (G) only reaches 87 million $€$ per year.

Our research further projected that flood risk in the Rhine basin will not be stationary and might considerably increase over a period of several decades. Expected annual damage in the entire Rhine basin may increase by between 54\% and $230 \%$, due to socio-economic and climate change. The results display large variations in current risk and floodrisk projections between regions along the Rhine. The increase in flood risk can mainly be attributed to increasing probabilities of flood peaks due to climate change (43-160\%, which is $\sim 6 / 8$ of the total risk increase), whereas socioeconomic change accounts for $7.5-27 \%$ increase, which is $\sim 1 / 8$ of the total risk increase. This is in contrast with the findings of Bouwer et al. (2010), who found, for a Dutch polder, that the effects of socio-economic change and climate change are similar in magnitude (climate change: 46201\% increase; socio-economic change: $35-172 \%$ increase, which resulted in an estimated total increase of between 96 and 719\%). However, they used 2040 as scenario year, while we addressed 2030. Also, Bouwer et al. (2010) included projections for increasing capital value in their socio-economic scenarios, in addition to projections for landuse change. This accounts for the major part of their estimate of the contribution from socio-economic change to total flood risk. When wealth increase is not included in Bouwer et al. (2010), the relative change in flood risk is much more similar (socio-economic change inflicts an increase of 3-44\%). We omitted wealth increase projections for the Rhine basin due to lack of reliable future projections for the entire basin.

Our method provides a more comprehensive assessment of basin-wide flood risk in the Rhine than was previously possible as existing studies either assessed flood risk in the Netherlands or in upstream areas in Germany (Apel et al., 2004; Klijn et al., 2007; Aerts et al., 2008; Bouwer et al., 2010). Furthermore, our method enables basin-wide scenario projections for future land use and potential damage, by integrating a land-use model with a damage model at a high spatial resolution. 


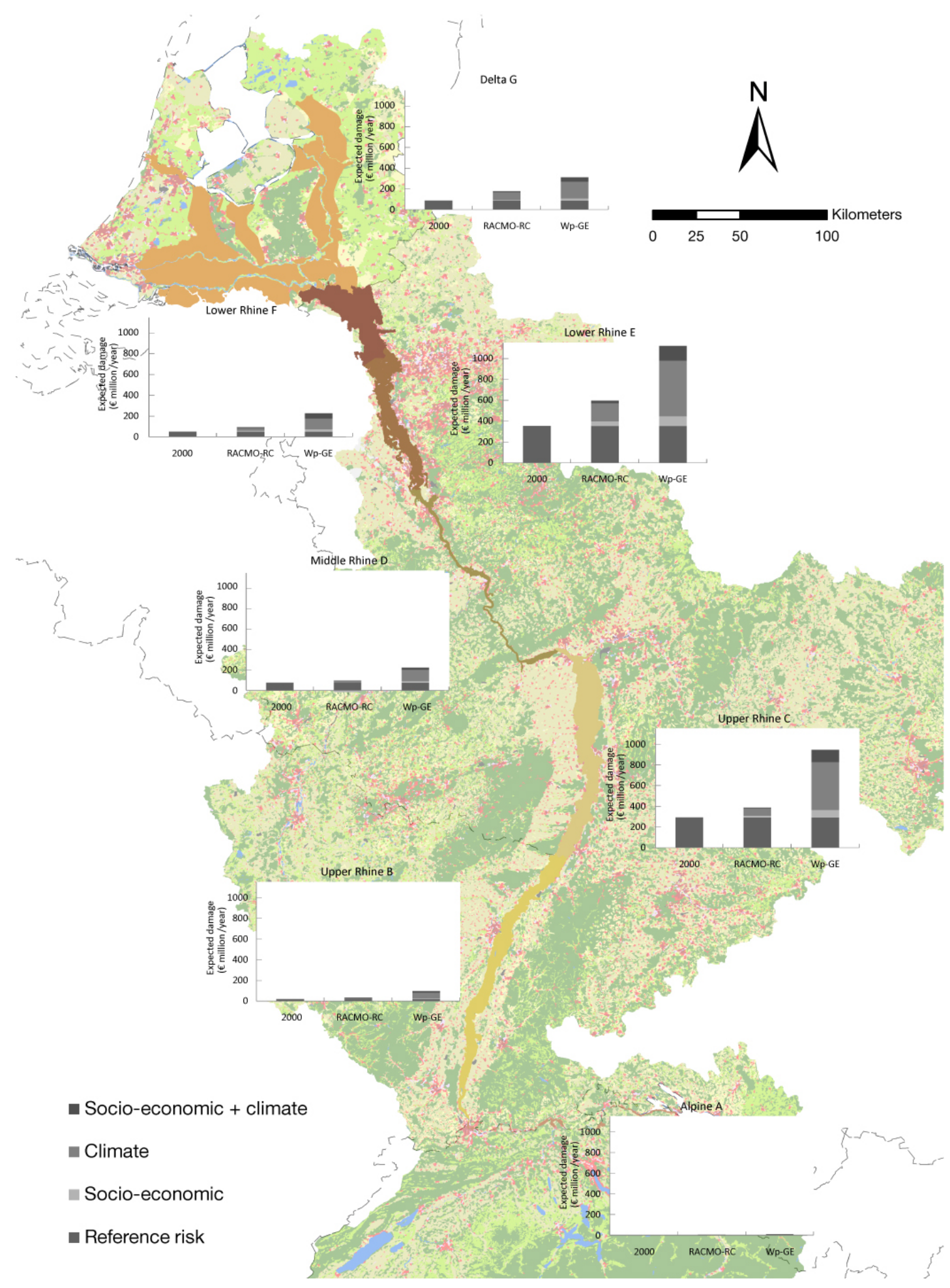

Fig. 7. Annual expected flood damage, for the reference situation and projections for 2030, aggregated into seven regions along the Rhine.

We have shown that expected annual damage depends heavily on estimated flood-probabilities. Further work might focus on acquiring actual safety levels along the Rhine in more detail, by analyzing dike heights and water levels. In reality, there are no jumps in dike height or thus in safety levels along the Rhine between countries or Bundesländer, as we assumed here, but instead the shift is gradual. In addition, due to dike failure processes such as piping, the actual 
flood-probability might be much higher than the probabilities of flood events dikes are designed to cope with (Ministry of Transport, Public Works and Water Management, 2006b). On the other hand, due to over dimensioning of dikes, flood probabilities can also be much lower than currently perceived. Understanding this requires more research, which is ongoing in detail in the Netherlands (Ministry of Transport, Public Works and Water Management, 2006b), but, to our knowledge, not on a large scale in Germany and France.

Flood damage estimates contain uncertainties related to the choice of the damage model and the simulation of inundation depth. The uncertainty in absolute damage estimates and increases can be considerable when applying damage models (Apel et al., 2009; Merz and Thieken, 2009; De Moel and Aerts, 2010). However, the relative damage increase (increase as a percentage compared to the reference) is much more robust De Moel and Aerts (2010). For this reason, the absolute values of flood risk increase presented in this paper should also be interpreted with care.

In our approach, we assumed for the Netherlands that all areas ("dike rings") will inundate during a flooding event, while they might only partly flood in reality. Therefore, both basin-wide potential damage, as well as expected annual damage, do not provide information on the damage of a single event. For the part of the Rhine basin upstream of the Netherlands, we used inundation maps from the Rhine Atlas (ICPR, 2001) that are to date the best available. The Rhine Atlas assumes flood prone areas to inundate completely. However, several 2-D hydrodynamic inundation simulations for the Lower Rhine by Lammersen (2004) showed that the flood-prone areas do not always entirely inundate, depending on breach locations and flood wave characteristics. We therefore recommend more inundation calculations upstream of the Netherlands which are currently only incidentally available, in order to aid further flood risk assessments.

Finally, the implementation of flood defence measures, such as retention basins and dike heightening, might prevent the increase in flood probability due to climate change, and thus the contribution of climate change to flood risk. This requires a thorough analysis of the effectiveness of flood management measures under different climate change scenarios. Spatial planning policies and damage mitigation measures and risk transfer mechanisms, such as flood proofing of buildings and insurance, might further reduce flood risk. Such flood risk decisions may have implications for several decades. Therefore, flood risk management needs to deal with expected climate and socio-economic changes (Merz et al., 2010).

Acknowledgements. We would like to thank Christian Lindner and the Institut für Raumplanung Universität Dortmund for providing spatial data for the land-use model. The comments made by our colleague Peter Verburg are also gratefully acknowledged. Finally, we thank Walter Pflügner and an anonymous reviewer for their valuable comments. This research project was carried out in the framework of the Dutch National Research Programme Knowledge for Climate (www.knowledgeforclimate.org), which is co-financed by the Ministry of Housing, Spatial Planning and the Environment (VROM). Furthermore, the project was financed by Deltares and the Dutch Ministry of Transport, Public Works and Water Management $(\mathrm{V} \& \mathrm{~W})$.

Edited by: T. Glade

Reviewed by: W. Pflügner and another anonymous referee

\section{References}

Aerts, J. C. J. H., Sprong, T., and Bannnik, B. A.: Aandacht voor Veiligheid (in Dutch), Leven met Water, Klimaat voor Ruimte, DG Water, Amsterdam, the Netherlands, 196 pp., 2008.

Apel, H., Thieken, A. H., Merz, B., and Blöschl, G.: Flood risk assessment and associated uncertainty, Nat. Hazards Earth Syst. Sci., 4, 295-308, doi:10.5194/nhess-4-295-2004, 2004.

Apel, H., Thieken, A. H., Merz, B., and Blöschl, G.: A probabilistic modelling system for assessing flood risks, Nat. Hazards, 38, 79_ 100, doi:10.1007/s11069-005-8603-7, 2006.

Apel, H., Aronica, G. T., Kreibich, H., and Thieken, A. H.: Flood risk analyses-how detailed do we need to be?, Nat. Hazards, 49, 79-98, doi:10.1007/s11069-008-9277-8, 2009.

Bakker, A. M. R. and Van den Hurk, B. J. J. M.: Bias correction and resampling of RACMO output for the hydrological modelling of the Rhine, Rep. Nr. TR-307, KNMI, De Bilt, the Netherlands, 2009.

Bergström, S.: Development and application of a conceptual runoff model for Scandinavian catchments, Ph.D. thesis, SMHI Reports RHO 7, Swedish Meteorological and Hydrological Institute (SMHI), Norköping, Sweden, 1976.

Blackbourn, D.: The conquest of nature: water, landscape, and the making of modern Germany, Norton, London, UK, 2006.

Bossard, M., Feranec, J., and Otahel, J.: CORINE land cover technical guide - Addendum 2000, Rep. Nr. 40, European Environment Agency, Copenhagen, Denmark, 2000.

Bouwer, L. M., Crompton, R. P., Faust, E., Höppe, P., and Pielke Jr., R. A.: Confronting Disaster Losses, Science, 318, p. 753, doi:10.1126/science.1149628, 2007.

Bouwer, L. M., Bubeck, P., and Aerts, J. C. J. H.: Changes in future flood risk due to climate and development in a Dutch polder area, Global Environ. Chang., 20, 463-471, 2010.

Brakenridge, G. R. and Anderson, E.: Darthmouth Flood Observatory, available at: http://www.dartmouth.edu/ floods/, last access: 8 March 2008.

Bronstert, A., Niehoff, D., and Bürger, G.: Effects of climate and land-use change on storm runoff generation: present knowledge and modelling capabilities, Hydrol. Process., 16, 509-529, doi:10.1002/hyp.326, 2002.

Büchele, B., Kreibich, H., Kron, A., Thieken, A., Ihringer, J., Oberle, P., Merz, B., and Nestmann, F.: Flood-risk mapping: contributions towards an enhanced assessment of extreme events and associated risks, Nat. Hazards Earth Syst. Sci., 6, 485-503, doi:10.5194/nhess-6-485-2006, 2006.

CEA: Reducing the Social and Economic Impact of Climate Change and Natural Catastrophes Insurance Solutions and Public-Private Partnerships, Brussels, Belgium, 48 pp., 2007. 
De Bruijn, K. and Klijn, F.: Risky places in the Netherlands: a first approximation for floods, Journal of Flood Risk Management, 2, 58-67, doi:10.1111/j.1753-318X.2009.01022.x, 2009.

De Moel, H. and Aerts, J. C. J. H.: Effect of uncertainty in land use, damage curves and inundation depth on flood damage estimates, Nat. Hazards, in press, doi:10.1007/s11069-010-9675-6, 2010.

De Moel, H., van Alphen, J., and Aerts, J. C. J. H.: Flood maps in Europe - methods, availability and use, Nat. Hazards Earth Syst. Sci., 9, 289-301, doi:10.5194/nhess-9-289-2009, 2009.

De Moel, H., Aerts, J. C. J. H., and Koomen, E.: Development of flood risk in the Netherlands during the $20^{\text {th }}$ and $21^{\text {st }}$ century, Global Environ. Chang., in press, doi:10.1016/j.gloenvcha.2010.12.005, 2010.

Dekkers, J. E. C. and Koomen, E.: Land-use simulation for water management: application of the Land Use Scanner model in two large-scale scenario-studies, in: Modelling land-use change; progress and applications, Springer, Dordrecht, the Netherlands, 355-373, 2007.

Engel, H.: The flood events of 1993/1994 and 1995 in the Rhine River basin, in: Destructive Water: Water-Caused Natural Disasters, their Abatement and Control, IAHS Publication no. 239, edited by: Leavesly, G. H., Lins, H. F., Nobilis, F., Parker, R. S., Schneider, V. R., and Van de Ven, F. H. M., IAHS Press, Wallingford, UK, 1997.

Environment Agency: Review of 2007 summer floods, Rep. Nr. GEHO1107BNMI-E-P, Almondsbury, Bristol, UK, 2007.

EU: Directive 2007/60/EC of the European Parliament and of the Council of 23 October 2007 on the assessment and management of flood risks, Commission of the European communities (EU), Brussels, Belgium, 2007.

Glaser, R. and Stangl, H.: Historical floods in the Dutch Rhine Delta, Nat. Hazards Earth Syst. Sci., 3, 605-613, doi:10.5194/nhess-3-605-2003, 2003.

Gudden, J.: Grensoverschrijdende effecten van extreem hoog water op de Niederrhein, Deelrapport overstromingen in Nordrhein-Westfalen en Gelderland, Ministerium für Umwelt und Naturschutz, Landwirtschaft und Verbraucherschutz des Landes Nordrhein-Westfalen and Province Gelderland and Minstry of Transport, Public Works and Water Management, Arnhem, the Netherlands, 2004 (in Dutch).

Hartje, V., Klaphake, A., Grossman, M., Mutafoglu, K., Borgwardt, J., Blazejczak, J., Gornig, M., Ansman, T., Koomen, E., and Dekkers, J.: Regional Projection of Water Demand and Nutrient Emissions - The GLOWA-Elbe approach, poster presented at the Statuskonferenz Glowa-Elbe II, Cologne, Germany, 18-19 May 2005.

Hilferink, M. and Rietveld, P.: Land Use Scanner: An integrated GIS based model for long term projections of land use in urban and rural areas, J. Geogr. Syst., 1, 155-177, 1999.

Hooijer, A., Klijn, F., Pedroli, G. B. M., and Van Os, A. G.: Towards sustainable flood risk management in the Rhine and Meuse basins: synopsis of the findings of IRMA-SPONGE, River Res. Appl., 20, 343-357, doi:10.1002/rra.781, 2004.

ICPR: Atlas 2001. Atlas of flood danger and potential damage due to extreme floods of the Rhine, International Commission on the Protection of the Rhine, Koblenz, Germany, available at: http: //www.iksr.org/, 2001.

ICPR: Action Plan on Floods. Kurzfassung Bericht Nr. 156, International Commission on the Protection of the Rhine,
Koblenz, Germany, 2005a.

ICPR: Nachweisinstrumente für die Reduzierung von Schadensrisiken, Rep. Nr. 157, International Commission for the Protection of the Rhine, Koblenz, Germany, 29 pp., 2005b (in German)

IPCC: Special report on emission scenarios - a special report of working group III of the Intergovernmental Panel on Climate Change, 2000.

Jonkeren, O. E.: Adaptation to climate change in inland waterway transport, Ph.D. thesis, VU University, Amsterdam, the Netherlands, 2009.

Klijn, F., Baan, P., De Bruijn, K., and Kwadijk, J.: Overstromingsrisico's in Nederland in een veranderend klimaat. Verwachtingen, schattingen en berekeningen voor het project Nederland Later, Tech. rep., Milieu en Natuurplan bureau (MNP), WL | Delft Hydraulics, Delft, the Netherlands, 2007 (in Dutch).

Koomen, E., Kuhlman, T., Groen, J., and Bouwman, A. A.: Simulating the future of agricultural land use in the Netherlands, Tijdschr. Econ. Soc. Ge., 96, 218-224, 2005 (in Dutch).

Kreibich, H. and Thieken, A.: Coping with floods in the city of Dresden, Germany, Nat. Hazards, 51, 423-436, doi:10.1007/s11069-007-9200-8, 2009.

Kwadijk, J. C. J.: The impact of climate change on the discharge of the River Rhine, Ph.D. thesis, Department of Physical Geography, University of Utrecht, the Netherlands, 1993.

Lammersen, R.: Cross-boundary effects of extreme peak discharges at the Lower Rhine, Endreport, Tech. rep., Ministerium für Umwelt und Naturschutz, Landwirtschaft und Verbraucherschutz des Landes Nordrhein-Westfalen, Province Gelderland, Ministry of Transport, Public Works and Water Management, Arnhem, the Netherlands, 2004 (in Dutch).

Lammersen, R., Engel, H., Van den Langenheem, W., and Buiteveld, H.: Impact of river training and retention measures on flood peaks along the Rhine, J. Hydrol., 267, 115-124, doi:10.1016/S0022-1694(02)00144-0, 2002.

Landscan: LandScanTM Global Population Database, Oak Ridge National Laboratory, available at: http://www.ornl.gov/ landscan/, last access: 9 May 2009.

Lenderink, G., Van den Hurk, B., Van Meijgaard, E., Van Ulden, A. P., and Cuijpers, J.: Simulation of present-day climate in RACMO2: First results and model developments, Rep. Nr. 252, KNMI, De Bilt, the Netherlands, 2003.

Loonen, W. and Koomen, E.: Calibration and validation of the Land Use Scanner allocation algorithms, Milieu- en Natuurplanbureau, De Bilt, the Netherlands, 2008.

Meijgaard, E., Van Ulft, L. H., Van den Berg, W. J., Bosveld, F. C., Van den Hurk, B. J. J. M., Lenderink, G., and Siebesma, A. P.: The KNMI regional atmospheric climate model RACMO, version 2.1., Rep. Nr. 302, KNMI, De Bilt, the Netherlands, 2008.

Menzel, L., Thieken, A. H., Schwandt, D., and Bürger, G.: Impact of climate change on the regional hydrology - scenario-based modelling in the German Rhine catchment, Nat. Hazards, 38, 45-61, 2006.

Merz, B. and Thieken, A.: Flood risk curves and uncertainty bounds, Nat. Hazards, 51, 437-458, doi:10.1007/s11069-0099452-6, 2009.

Merz, B., Kreibich, H., Thieken, A., and Schmidtke, R.: Estimation 
uncertainty of direct monetary flood damage to buildings, Nat. Hazards Earth Syst. Sci., 4, 153-163, doi:10.5194/nhess-4-1532004, 2004.

Merz, B., Thieken, A. H., and Gocht, M.: Flood Risk Mapping At The Local Scale: Concepts and Challenges, in: Flood Risk Management in Europe, edited by: Begum, S., Stive, M., and Hall, J., Springer, Dordrecht, the Netherlands, Chap. 13, 231251, doi:10.1007/978-1-4020-4200-3-13, 2007.

Merz, B., Hall, J., Disse, M., and Schumann, A.: Fluvial flood risk management in a changing world, Nat. Hazards Earth Syst. Sci., 10, 509-527, doi:10.5194/nhess-10-509-2010, 2010.

Messner, F., Roswell, E. P., Green, C., Meyer, V., Tunstall, S., and Van der Veen, A.: Evaluating flood damages: guidance and recommendations on principles and practices, Rep. Nr. T09-0601, FLOODsite report, 2007.

Middelkoop, H., Daamen, K., Gellens, D., Grabs, W., Kwadijk, J. C. J., Lang, H., Parmet, B. W. A. H., Schadler, B., Schulla, J., and Wilke, K.: Impact of climate change on hydrological regimes and water resources management in the Rhine basin, Climatic Change, 49, 105-128, doi:10.1023/A:1010784727448, 2001.

Ministry of Transport, Public Works and Management: Hydraulische Randvoorwaarden 2006 voor het toetsen van primaire waterkeringen voor dederde toetsronde 2006-2011, The Hague, the Netherlands, 2006a (in Dutch).

Ministry of Transport, Public Works and Water Management: Flood Risks and Safety in the Netherlands (Floris) - Full Report, Rep. Nr. DWW-2006-014, The Hague, the Netherlands, 2006b.

MNP: Nederland Later; Tweede Duurzaamheidsverkenning deel fysieke leefomgeving Nederland, Tech. Rep. 500127001/2007, Milieu- en Natuurplanbureau, De Bilt, the Netherlands, 2007 (in Dutch).

Pielke Jr., R. A., Gratz, J., Landsea, C., Collins, D., Saunders, M., and Musulin, R.: Normalized hurricane damages in the United States: 1900-2005, Natural Hazards Review, 9, 29-42, doi:10.1061/(ASCE)1527-6988(2008)9:1(29), 2008.

Pinter, N., Van der Ploeg, R. R., Schweigert, P., and Hoefer, G.: Flood magnification on the River Rhine, Hydrol. Process., 20, 147-164, doi:10.1002/hyp.5908, 2006.

Raff, D. A., Pruitt, T., and Brekke, L. D.: A framework for assessing flood frequency based on climate projection information, Hydrol. Earth Syst. Sci., 13, 2119-2136, doi:10.5194/hess-13-21192009, 2009.

RebelGroup: Indirecte effecten overstromingen in het kader van HIS-SSM en de KBA WV21, RebelGroup Advisory Belgium, Antwerp, Belgium, 2007 (in Dutch).

Ritsema van Eck, J. and Koomen, E.: Characterising urban concentration and land-use diversity in simulations of future land use, Ann. Regional Sci., 42, 123-140, 2008.

Shabalova, M. V., Van Deursen, W. P. A., and Buishand, T. A.: Assessing future discharge of the River Rhine using regional climate model integrations and a hydrological model, Clim. Res., 23, 233-246, 2003.
Silva, W. and Van Velzen, E.: De dijk van de toekomst?, Quick scan Doorbraakvrije dijken, Ministry of Transport, Public Works and Water Management, The Hague, the Netherlands, 2008 (in Dutch).

Te Linde, A. H.: Effect of climate change on the discharge of the rivers Rhine and Meuse. Applying the KNMI 2006 scenarios using the HBV model, WL | Delft Hydraulics, Delft, the Netherlands, 2007.

Te Linde, A. H., Aerts, J. J. C. H., Bakker, A. M. R., and Kwadijk, J. C. J.: Simulating low probability peak discharges for the Rhine basin using resampled climate modeling data, Water Resour. Res., 46, W03512, doi:10.1029/2009WR007707, 2010.

Thieken, A. H., Olschewski, A., Kreibich, H., Kobsch, S., and Merz, B.: Development and evaluation of FLEMOps - a new Flood Loss Estimation MOdel for the private sector, in: Flood Recovery, Innovation and Response I, edited by: Proverbs, D., Brebbia, C., and Penning-Roswell, E., WIT, Ashurst, UK, 2008.

Van den Berg, A., Alberts, F., and Ligthart, N.: Overstromingsrisicokaarten, available at: http://www.risicokaart.nl/, last access: 4 April 2010 (in Dutch).

Van den Hurk, B., Klein Tank, A., Lenderink, G., Van Ulden, A., Van Oldenborgh, G., Katsman, C., Van den Brink, H., Keller, F., Bessembinder, J., Burgers, G., Komen, G., Hazeleger, W., and Drijfhout, S.: KNMI Climate Change Scenarios 2006 for the Netherlands, Rep. Nr. WR 2006-01, KNMI, De Bilt, the Netherlands, 2006.

Vellinga, P., Mills, E., Berz, G., Bouwer, L., Huq, S., Kozak, L., Palutikof, J., Schanzenbacher, B., and Soler, G.: Insurance and other financial services, in: Climate Change 2001: Impacts, Adaptation, and Vulnerability. Contribution of Working Group II to the Third Assessment Report of the Intergovernmental Panel on Climate Change, edited by: McCarthy, J., Canziani, O., Leary, N., Dokken, D., and White, K., 417-450, Cambridge University Press, Cambridge, UK, 2001.

Verburg, P. H. and Overmars, K. P.: Combining top-down and bottom-up dynamics in land use modeling: exploring the future of abandoned farmlands in Europe with the Dyna-CLUE model, Landscape Ecol., 24, 1167-1181, doi:10.1007/s10980009-9355-7, 2009.

Verburg, P. H., Eickhout, B., and Van der Meijl, H.: A multi-scale, multi-model approach for analyzing the future dynamics of European land use, Ann. Regional Sci., 42, 57-77, doi:10.1007/s00168-007-0136-4, 2008.

Wagtendonk, A. J., Julião, R. P., and Schotten, C. G. J.: A regional planning application of Euroscanner in Portugal, in: Land Use Simulation for Europe, edited by: Stillwell, J. and Scholten, H., Kluwer Academic Publishers, Amsterdam, the Netherlands, 293 pp., 2001.

Wheater, H. and Evans, E.: Land use, water management and future flood risk, Land Use Policy, 26, S251-S264, doi:10.1016/j.landusepol.2009.08.019, 2009. 